\title{
NEUROPEPTIDE Y PROTECTS RETINAL NEURAL CELLS AGAINST CELL DEATH INDUCED BY ECSTASY
}

\author{
A. R. ÁLVARO, ${ }^{a}$ J. MARTINS, ${ }^{a}$ A. C. COSTA, ${ }^{a}$ \\ E. FERNANDES, ${ }^{b}$ F. CARVALHO,${ }^{c}$ A. F. AMBRÓSIO ${ }^{a, d}$ \\ AND C. CAVADAS ${ }^{a, e *}$ \\ ${ }^{a}$ Center for Neuroscience and Cell Biology, University of Coimbra, \\ Portugal \\ ${ }^{b}$ REQUIMTE, Physical-Chemistry Department, Faculty of Pharmacy, \\ University of Porto, Portugal \\ ${ }^{c}$ REQUIMTE, Toxicology Department, Faculty of Pharmacy, University \\ of Porto, Portugal \\ ${ }^{d}$ Center of Ophthalmology of Coimbra, IBILI, Faculty of Medicine, \\ University of Coimbra, Portugal \\ ${ }^{\circ}$ Faculty of Pharmacy, University of Coimbra, Rua do Norte, 3020-123 \\ Coimbra, Portugal
}

\begin{abstract}
Ecstasy (3,4-methylenedioxymethamphetamine; MDMA) has potent CNS stimulant effects. Besides the acute effects of MDMA, such as psychomotor activation, euphoria, decreased appetite, and hyperthermia, long-term damage of dopaminergic and serotonergic nerve terminals in multiple brain areas have also been reported. Although some studies have demonstrated that considerable amounts of MDMA reach the vitreous humor of the eye, and that serious visual consequences can result from MDMA consumption, the toxic effect of MDMA on the retina has not been completely elucidated. Neuropeptide Y (NPY) is present in the CNS, including the retina. The aim of the present study was to evaluate the effect of MDMA on rat retinal neural cell viability and investigate the involvement of $5-\mathrm{HT} 2 \mathrm{~A}$-receptor $\left(5-\mathrm{HT}_{2 \mathrm{~A}}\right)$ activation. Moreover, the neuroprotective role of NPY on MDMAinduced toxicity was also investigated. MDMA induced necrosis [MTT (3-(4,5-dimethylthiazol-2-yl)-2,5-diphenyltetrazolium bromide) and propidium iodide assays] and apoptosis (immunoreactivity of cleaved caspase-3) in mixed cultures of retinal neural cells (neurons, macroglia and microglia), in a concentrationdependent manner. MDMA-induced toxicity was enhanced at higher temperature $\left(40{ }^{\circ} \mathrm{C}\right)$ and was reduced by the $5 \mathrm{HT}_{2 \mathrm{~A}^{-}}$ receptor antagonist, ketanserin $(1 \mu \mathrm{M})$. Interestingly, necrotic and apoptotic cell death induced by MDMA was inhibited by NPY (100 nM).

In conclusion, MDMA induces cell death in retinal neural cells, which is potentiated by elevated temperature. The toxic effect of MDMA involves the activation of $5-\mathrm{HT}_{2 \mathrm{~A}}$-receptor and can be inhibited by exogenous NPY. Thus, NPY or NPY analogues might be useful agents against retinal degeneration induced by drugs or in neurodegenerative eye diseases. (C) 2008 IBRO. Published by Elsevier Ltd. All rights reserved.
\end{abstract}

${ }^{*}$ Correspondence to: C. Cavadas, Faculty of Pharmacy, University of Coimbra, Rua do Norte, 3020-123 Coimbra, Portugal.

E-mail address: ccavadas@ff.uc.pt (C. Cavadas).

Abbreviations: BSA, bovine serum albumin; $\left[\mathrm{Ca}^{2+}\right]_{i}$, intracellular calcium concentration; FBS, fetal bovine serum; GFAP, glial fibrillary acidic protein; Hepes, (4-(2-hydroxyethyl)-1-piperazineethanesulfonic acid); MDMA, 3,4-methylenedioxymethamphetamine (ecstasy); MEM, Minimum Essential Medium; MTT, 3-(4,5-dimethylthiazol-2-yl)-2,5-diphenyltetrazolium bromide; NPY, neuropeptide Y; PBS, phosphate-buffered saline; PI, propidium iodide.
Key words: MDMA, retina, NPY, toxicity, apoptosis, neuroprotection.

The recreational drug 3,4-methylenedioxymethamphetamine (MDMA; "ecstasy", "Adam", "X", "e"), often ingested at dance clubs, is a ring-substituted phenyl-isopropylamine that is related to both amphetamines and hallucinogens (Parrott, 2005; Cadet et al., 2007). The effects of MDMA are mediated, in part, by the increased release of 5-HT and subsequent stimulation of $5-\mathrm{HT}$ receptors (Ricaurte et al., 2000).

MDMA is known to cause degeneration of 5-HT nerve terminals in different animal models (Stone et al., 1986; Schmidt, 1987; Ricaurte et al., 1988b). After MDMA chronic ingestion, a decrease in 5-HT levels and its metabolite, 5-hydroxyindoleacetic acid (5-HIAA), in the number of 5-HT uptake sites, and also in tryptophan hydroxylase (TPH) activity was observed (Commins et al., 1987; Ricaurte et al., 1988a,b, 1992; Green et al., 2003; Xie et al., 2006). Other studies reported that the post-synaptic $5-\mathrm{HT}_{2 \mathrm{~A}}$-receptor is involved in the mechanism of MDMAinduced toxicity (Schmidt et al., 1990; Johnson et al., 1993; Malberg et al., 1996; Capela et al., 2006, 2007). Other studies showed that MDMA-induced cell death occurs mainly by apoptosis, via caspase-3 activation (MontielDuarte et al., 2002; Jimenez et al., 2004; Meyer et al., 2004; Cunha-Oliveira et al., 2006; Tamburini et al., 2006; Warren et al., 2007).

A major feature of clinical cases related to MDMA toxicity is hyperthermia. Body temperatures reaching up to $43{ }^{\circ} \mathrm{C}$ have been reported (Henry, 1992; Green et al., 2003). This is of extreme importance, since ecstasy is often consumed at "rave" parties, where dancing takes place in a warm environment that could exacerbate the effect of MDMA on thermoregulation. In animal studies, the increase in core temperature of MDMA-treated animals enhances neurotoxicity (Malberg and Seiden, 1998; Carvalho et al., 2002).

Although MDMA was detected in significant amounts in the eye globe and vitreous humor (Clauwaert et al., 2000; De Letter et al., 2000, 2002), and some serious consequences to vision have been reported in MDMA users (Jacks and Hykin, 1998; Michael et al., 2003; Firth, 2006), the effect of MDMA on the retina has only been examined in one very recent study (Miranda et al., 2007).

Neuropeptide $Y$ (NPY) is a 36 amino acid peptide that belongs to NPY family, and its actions are mediated by six G-protein-coupled receptor subtypes, $Y_{1}, Y_{2}, Y_{3}, Y_{4}, Y_{5}$ and $\mathrm{y}_{6}$ (Michel et al., 1998; Silva et al., 2002). NPY is one of the most abundant and widely distributed neuropeptides 
in the mammalian CNS, being involved in various physiological functions, including feeding, memory processing and cognition (Wettstein et al., 1995; Silva et al., 2005a). It has also been reported that NPY has a neuroprotective role against excitotoxicity in rat hippocampus (Silva et al., 2003a,b, 2005b). Moreover, it was recently described that NPY has a protective role against methamphetamine-induced neuronal apoptosis in the mouse striatum (Thiriet et al., 2005). NPY and its receptors are present in the retina of different mammalian and non-mammalian species (Bruun et al., 1986; Jen et al., 1994; Hutsler and Chalupa, 1995; Oh et al., 2002; D'Angelo and Brecha, 2004; Álvaro et al., 2007). Recently we showed that primary cell cultures of rat retinal neural cells express NPY and NPY receptors (Álvaro et al., 2007).

The aim of the present study was to evaluate the putative protective role of NPY in MDMA-induced toxicity of rat retinal neural cells. We used primary cell cultures of rat retinal neural cells and tested different MDMA concentrations $(100-1600 \mu \mathrm{M})$ for $48 \mathrm{~h}$, at normothermic $\left(37^{\circ} \mathrm{C}\right)$ and hyperthermic conditions $\left(40^{\circ} \mathrm{C}\right)$. The type of cell death (necrosis/apoptosis) and changes in morphology of different retinal cell types were also evaluated.

\section{EXPERIMENTAL PROCEDURES}

\section{Materials}

Minimum Essential Medium (MEM), ketanserin, penicillin, streptomycin, bovine serum albumin (BSA), Hepes, poly-D-lysine, 3-(4,5-dimethylthiazol-2-yl)-2,5-diphenyltetrazolium bromide (MTT), propidium iodide (PI), and the anti-glial fibrillary acidic protein (GFAP) antibody were purchased from Sigma Chemical, St. Louis, MO, USA. The fetal bovine serum (FBS) was obtained from Biochrom, Berlin, Germany. Trypsin was purchased from Gibco BRL, Life Technologies, Scotland, UK. NPY was purchased from Novabiochem, Laufelfingen, Switzerland. The rabbit anti-cleaved caspase-3 (Asp 175) antibody was purchased from Cell Signaling, Danvers, MA, USA. The antibody to anti-CD68 (ED1), a marker of activated microglial cells, was obtained from Serotec, Raleigh, NC, USA. The antiTUJ1 antibody was purchased from Covance Research Products Inc, Berkeley, CA, USA. Hoechst 33342 dye was obtained from Molecular Probes, Eugene, OR, USA. The secondary antibodies, Alexa $^{\mathrm{TM}} 488$ anti-mouse $\operatorname{lgG}$ and Alexa ${ }^{\mathrm{TM}} 488$ anti-rabbit lgG were purchased from Invitrogen, Eugene, Oregon, USA.

\section{Rat retina neural cell cultures}

All procedures involving animals were in compliance with the Association for Research in Vision and Ophthalmology (ARVO) statement for vision and ophthalmic research. All efforts were made to minimize the number of animals used and their suffering. Wistar rat pups (3-5 days old) were used to prepare mixed primary cultures of retinal cells as previously described (Santiago et al., 2006). Briefly, retinas were dissected under sterile conditions, using a light microscope, in $\mathrm{Ca}^{2+}$ - and $\mathrm{Mg}^{2+}$-free Hanks' balanced salt solution (in mM: $137 \mathrm{NaCl}, 5.4 \mathrm{KCl}, 0.45 \mathrm{KH}_{2} \mathrm{PO}_{4}, 0.34$ $\mathrm{Na}_{2} \mathrm{HPO}_{4}, 4 \mathrm{NaHCO}_{3}, 5$ glucose, $\mathrm{pH} 7.4$ ), and digested with $0.1 \%$ trypsin (w/v) for $15 \mathrm{~min}$ at $37^{\circ} \mathrm{C}$. Cells were diluted in MEM, supplemented with $25 \mathrm{mM}$ Hepes, $26 \mathrm{mM} \mathrm{NaHCO}_{3}, 10 \% \mathrm{FBS}$ and penicillin $(100 \mathrm{U} / \mathrm{mL})$-streptomycin $(100 \mu \mathrm{g} / \mathrm{mL})$, and plated on poly-D-lysine $(0.1 \mathrm{mg} / \mathrm{mL})$-coated coverslips or 24 -multiwell plates for 9 days, at a density of $2 \times 10^{6}$ cells $/ \mathrm{cm}^{2}\left(37^{\circ} \mathrm{C}, 5 \% \mathrm{CO}_{2}\right)$.

\section{Cell viability studies}

MTT reduction assay. Cell viability was evaluated using the MTT reduction assay that measures the reducing capacity of cells, an general indicator of metabolic function. MTT is taken up by living cells and converted from a yellow to a water-insoluble bluecolored product by cellular dehydrogenases (Mosmann, 1983). Rat retinal cells cultured in 24-well plates were exposed to MDMA $(100,200,400,800$ and $1600 \mu \mathrm{M})$ for $48 \mathrm{~h}$, at $37^{\circ} \mathrm{C}$ or $40^{\circ} \mathrm{C}$. After incubation with MDMA, cells were washed twice with Krebs buffer (in mM: $132 \mathrm{NaCl}, 4 \mathrm{KCl}, 1.4 \mathrm{MgCl}_{2}, 1 \mathrm{CaCl}_{2}, 6$ glucose, 10 Hepes, $\mathrm{pH} 7.4$ ), and then cell viability was evaluated. Cells were incubated with MTT $(0.5 \mathrm{mg} / \mathrm{mL})$ in Krebs buffer for $1 \mathrm{~h}$ at $37^{\circ} \mathrm{C}$. After incubation, the medium was removed and the formazan crystals formed were dissolved with $0.04 \mathrm{M} \mathrm{HCl}$ in isopropanol. The extent of MTT reduction was measured with a spectrophotometer at $570 \mathrm{~nm}$. All experiments were carried out in triplicate. The cell content of reduced tetrazolium salt was expressed as the percentage of absorbance comparing to control cells.

PI staining. PI [3,8-diamino-5-(3-(diethylmethylamino)propyl)-6-phenyl phetananthridinium diiodide] is a polar substance that is only absorbed by dead or dying cells with disrupted cell membranes due to necrosis or late apoptosis, and binds to DNA emitting a bright red fluorescence $(630 \mathrm{~nm})$ when excited by blue-green light $(493 \mathrm{~nm})$. Cells plated on coverslips were exposed to MDMA (100, 200400,800 and $1600 \mu \mathrm{M})$ for $48 \mathrm{~h}$, at $37^{\circ} \mathrm{C}$ or $40^{\circ} \mathrm{C}$. In order to test a potential protective role of NPY, cells were also incubated with NPY $100 \mathrm{nM}$ before exposure to MDMA. The protective role of ketanserin $\left(5-\mathrm{HT}_{2 \mathrm{~A}}\right.$-receptor antagonist) was also evaluated. After drug incubations, the cells were washed twice and incubated with $\mathrm{PI}(0.04 \mathrm{mg} / \mathrm{mL})$ for $3 \mathrm{~min}$, and then observed with a fluorescence microscope (Zeiss Axioshop 2 Plus) coupled to an Axiocam HRc camera. The number of PI positive cells was counted in five random fields in each coverslip, and the average number of PI positive cells per random field was determined for each condition tested.

\section{Immunocytochemistry}

Rat retinal neural cells plated on coverslips were exposed to MDMA $(400,800$, and $1600 \mu \mathrm{M})$ for $48 \mathrm{~h}$ at $37^{\circ} \mathrm{C}$. After incubation, retinal cells were washed twice with phosphate-buffered saline (PBS) (137 mM NaCl, $27 \mathrm{mM} \mathrm{KCl}, 18 \mathrm{mM} \mathrm{KH}_{2} \mathrm{PO}_{4}, 100 \mathrm{mM}$ $\mathrm{Na}_{2} \mathrm{HPO}_{4}, \mathrm{pH} 7.4$ ) and fixed with $4 \%$ paraformaldehyde for $20 \mathrm{~min}$ at room temperature. Cells were permeabilized with $1 \%$ Triton $\mathrm{X}-100$ for $5 \mathrm{~min}$ at room temperature, and non-specific binding of the antibodies was prevented by incubation with $3 \%(\mathrm{w} / \mathrm{v})$ fatty acid-free bovine serum albumin supplemented with $0.2 \%$ Tween 20 for $1 \mathrm{~h}$. Cells were then incubated for $90 \mathrm{~min}$ at room temperature with the primary antibody: mouse anti-TUJ1 (neuronal marker, 1:500), mouse anti-GFAP (glial cell marker, 1:500), mouse anti CD68 antigen (ED1) (microglial cell marker; 1:200), and rabbit anti-cleaved caspase-3 (Asp175) (cleaved caspase-3 marker, 1:500). After incubation, cells were washed three times with PBS and incubated with the secondary antibody: Alexa ${ }^{\mathrm{TM}} 488$ goat anti-mouse IgG $(1: 200)$ or Alexa ${ }^{\mathrm{TM}} 488$ goat anti-rabbit IgG for $1 \mathrm{~h}$ at room temperature in the dark. Finally, after $5 \mathrm{~min}$ washing, cell nuclei were stained with Hoechst $33342(1 \mu \mathrm{g} / \mathrm{mL}$ in PBS) for $5 \mathrm{~min}$. Cells were washed twice in PBS and mounted using a Prolong Antifade Kit, Dako Cytomation, DK-2600 Glostrup, Denmark. All antibody solutions were prepared in 3\% fatty acid-free BSA solution. Cells were visualized with a Zeiss Axioshop 2 Plus microscope, coupled to an Axiocam HRc camera.

\section{Statistical analysis}

All data are presented as mean \pm S.E.M. Statistical analysis was performed using analysis of variance (ANOVA) followed by Dunnet's or Bonferroni's post-tests, as indicated in the figure legends. 


\section{RESULTS}

MDMA-induced cell death in cultured rat retinal neural cells: concentration and temperature dependency

The effect of MDMA on viability of cultured rat retinal neural cells was evaluated by the MTT reduction assay. Cells were exposed to MDMA (100 $\mu \mathrm{M}$ to $1600 \mu \mathrm{M})$, during $48 \mathrm{~h}$, under normothermic $\left(37^{\circ} \mathrm{C}\right)$ and hyperthermic $\left(40{ }^{\circ} \mathrm{C}\right.$ ) conditions (Fig. $\left.1 \mathrm{~A}, \mathrm{~B}\right)$. At $37^{\circ} \mathrm{C}$ and $40{ }^{\circ} \mathrm{C}$, there was a significant decrease in cell viability when retinal cells were exposed to $400 \mu \mathrm{M}, 800 \mu \mathrm{M}$ or $1600 \mu \mathrm{M}$ MDMA. The highest concentration of MDMA used (1600 $\mu \mathrm{M})$ decrease cell viability more in hyperthermic conditions $\left(40{ }^{\circ} \mathrm{C}\right)$ than in normothermic conditions $\left(37^{\circ} \mathrm{C}\right)(26.8 \% \pm 5.4 \%$ of the control, and $51.2 \pm 2.8 \%$ of the control, respectively). PI uptake was also used to evaluate the effect of MDMA on cell viability (Fig. 2). MDMA (400 $\mu \mathrm{M}, 800 \mu \mathrm{M}$ and $1600 \mu \mathrm{M})$ increased the number of $\mathrm{Pl}^{+}$cells $(318.7 \pm 67.0 \%$, $348.5 \pm 30.7 \%, 796.5 \pm 100.0 \%$ compared with control, respectively).

\section{Protective effect of a selective $5-\mathrm{HT}_{2 \mathrm{~A}}$-receptor antagonist against MDMA-induced toxicity}

The protective role of $5-\mathrm{HT}_{2 \mathrm{~A}}$-receptor blockade against MDMA-induced toxicity (at $37^{\circ} \mathrm{C}$ ) was evaluated by preincubating the cells with ketanserin $(1 \mu \mathrm{M}) 1 \mathrm{~h}$ before, and

\section{A $37^{\circ} \mathrm{C}$}

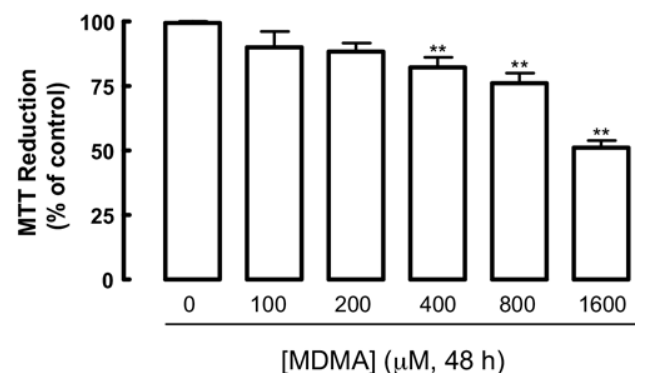

B $40^{\circ} \mathrm{C}$

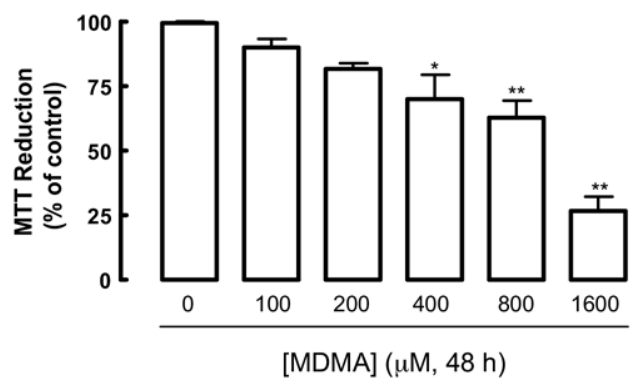

Fig. 1. MDMA decreases the viability of retinal cells: concentration and temperature dependency. Cultured rat retinal neural cells were exposed to MDMA $(100,200,400,800$ and $1600 \mu \mathrm{M})$ for $48 \mathrm{~h}$, at $37^{\circ} \mathrm{C}$ (A) and $40{ }^{\circ} \mathrm{C}$ (B). The results are expressed as percentage of MTT reduction in control conditions (no drug), and represent the mean \pm S.E.M. of at least three independent experiments performed in triplicate. ${ }^{*} P<0.05,{ }^{* *} P<0.01$, different from control, Dunnet's post hoc test. with ketanserine $(1 \mu \mathrm{M})$

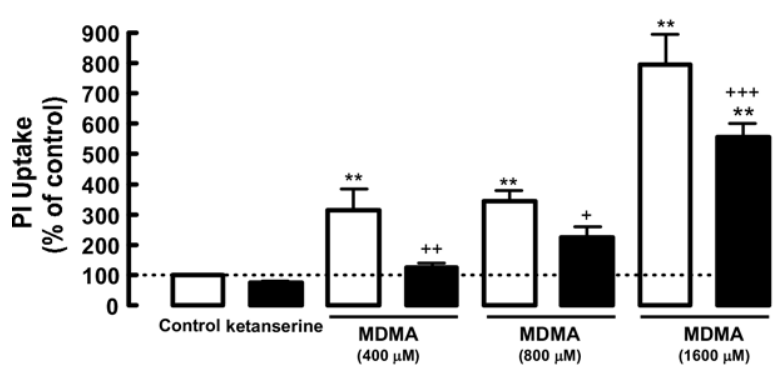

Fig. 2. Inhibition of $5 \mathrm{HT}_{2 \mathrm{~A}}$ receptors protects retinal cells against MDMA-induced cell death. $5 \mathrm{HT}_{2 \mathrm{~A}}$ receptors were inhibited by ketanserin $(1 \mu \mathrm{M})$, which was added to the cultures $1 \mathrm{~h}$ before the incubation with MDMA. Cell death was evaluated by PI uptake, as described in Experimental Procedures, and compared with control conditions (no drug). The results are expressed as percentage of $\mathrm{PI}$ positive cells in control conditions, and represent the mean \pm S.E.M. of at least three independent experiments. ${ }^{* *} P<0.01$ compared with control, Dunnet's post hoc test; ${ }^{+} P<0.05,{ }^{++} P<0.01,{ }^{+++} P<0.001$ compared with MDMA, Bonferroni's post hoc test.

during, MDMA incubation. Ketanserin significantly inhibited the increase in the number of $\mathrm{PI}^{+}$cells induced by MDMA (Fig. 2). Ketanserin alone did not change PI uptake compared with control.

Toxic effect of MDMA on different retinal neural cells: neurons, macroglial and microglial cells

By immunocytochemistry, we also evaluated the toxic effect of MDMA on different retinal neural cells. The toxic effect of MDMA on retinal neurons (TUJ1 positive cells), macroglial cells (GFAP positive cells) and microglial cells (ED1 positive cells) is shown in Fig. 3 . In the presence of MDMA (800 and $1600 \mu \mathrm{M}, 48 \mathrm{~h}, 37^{\circ} \mathrm{C}$ ) there were fewer cell nuclei compared with controls (Hoechst staining, Fig. $3 \mathrm{~A}, \mathrm{~B}, \mathrm{C})$. The number of neurons ( $\beta$-3-tubulin positive cells) was also less than control, and a retraction on cell processes was evident (Fig. 3D, E, F). Moreover, there were fewer GFAP-positive cells (Müller cells and astrocytes) compared with controls, after highest MDMA concentration used (Fig. 3G, H, I) and the number of microglial cells was also less in MDMA-treated cells compared with controls (Fig. 3J, K, L).

\section{Protective effect of NPY against MDMA-induced cell death}

The potential for NPY to protect against MDMA-induced retinal neural cell death was also investigated. NPY $(100 \mathrm{nM})$ inhibited the increase in the number of $\mathrm{PI}^{+}$retinal cells induced by MDMA (Fig. 4). We also found that when retinal cells were exposed to glutamate $(500 \mu \mathrm{M})$ for $48 \mathrm{~h}$, the number of $\mathrm{PI}^{+}$cells increased $(279.9 \pm 31.0 \%$ compared with control), and NPY inhibited this effect (121.1 $\pm 13.3 \%$ compared with control; $P<0.001$ compared with glutamate, $n=6)$.

NPY alone did not change PI uptake, compared with control (Fig. 4A, B, F). The appearance of cleaved caspase-3 immunoreactivity, used as a marker of apopto- 


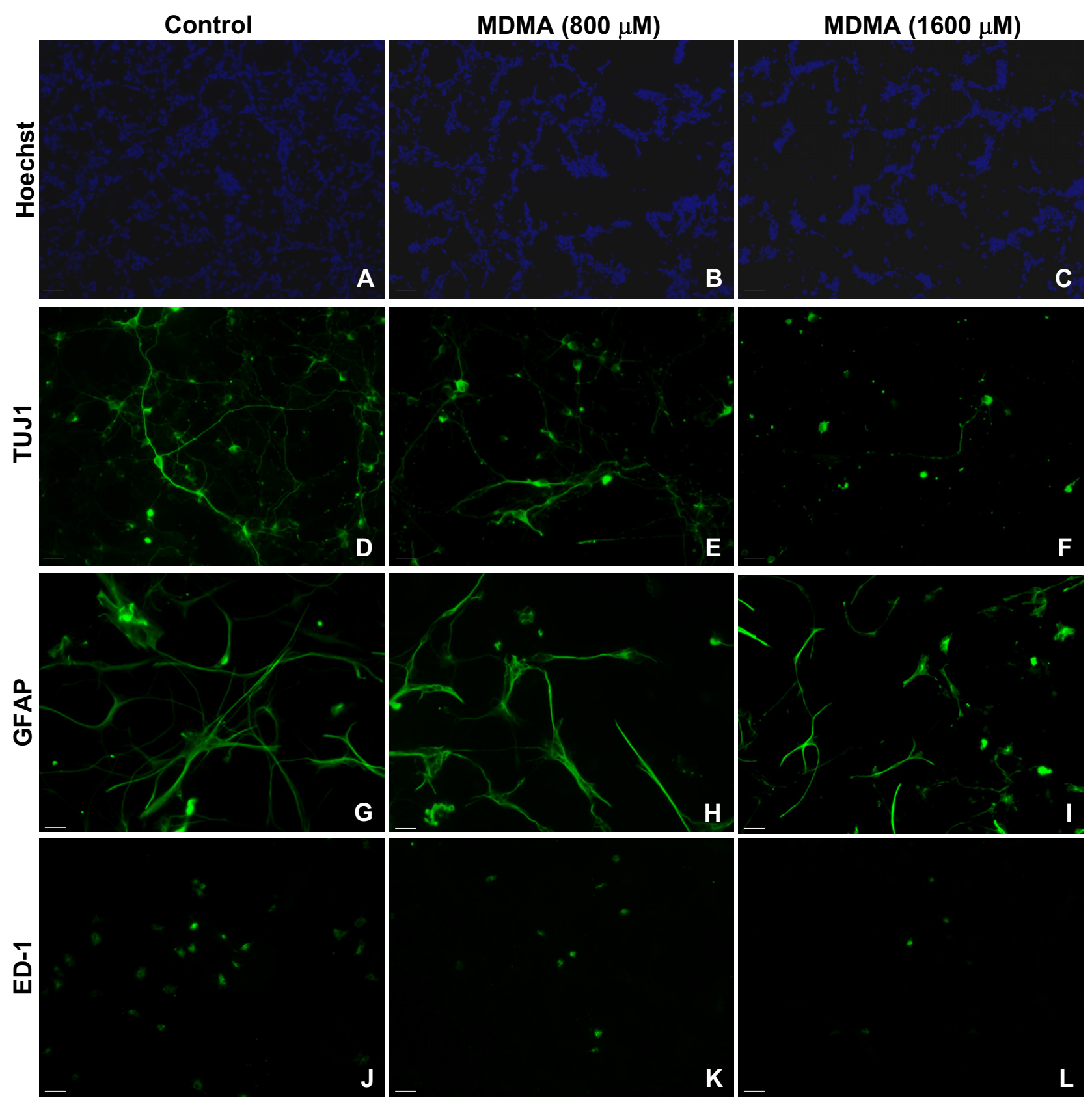

Fig. 3. Toxic effect of MDMA on different retinal neural cells. Neurons, macroglial cells (astrocytes and Müller cells) and microglial cells were identified by immunocytochemistry using antibodies against TUJ1 (D, E, F), GFAP $(G, H, I)$ and ED1 (J, K, L), respectively. Cell cultures were exposed to MDMA $(800$ and $1600 \mu \mathrm{M})$ for $48 \mathrm{~h}$. Cell nuclei were identified by Hoechst staining. The images are representative of three independent cell cultures. Scale bar $=20 \mu \mathrm{m}$.

sis, was also evaluated in retinal cultures exposed to MDMA, in the absence or in the presence of NPY (100 nM). The antibody that was used detects endogenous levels of the large fragment $(17 / 19 \mathrm{kDa})$ of activated caspase- 3 resulting from cleavage adjacent to $\mathrm{Asp}^{175}$, and does not recognize full length caspase-3 or other cleaved caspases. MDMA (400, 800 and $\left.1600 \mu \mathrm{M}, 37^{\circ} \mathrm{C}\right)$ increased the immunoreactivity of cleaved caspase-3 in retinal cells (Fig. 5). In control conditions, as well as in NPY-treated cultures, only a few cells were positive for cleaved caspase-3 (Fig. 5B, F). However, the number of caspase 3-positive cells was significantly increased in cell cultures exposed to $400 \mu \mathrm{M}, 800 \mu \mathrm{M}$ and $1600 \mu \mathrm{M}$ MDMA (Fig. 5). Additionally, to determine whether the protective mechanism of NPY was through inhibition of apoptosis, the immunoreactivity of activated caspase-3 was evaluated in retinal cells exposed to MDMA plus NPY (100 nM). The presence of NPY significantly decreased the number of activated caspase 3-positive cells induced by MDMA (Fig. 5). 
A

with NPY (100 nM)
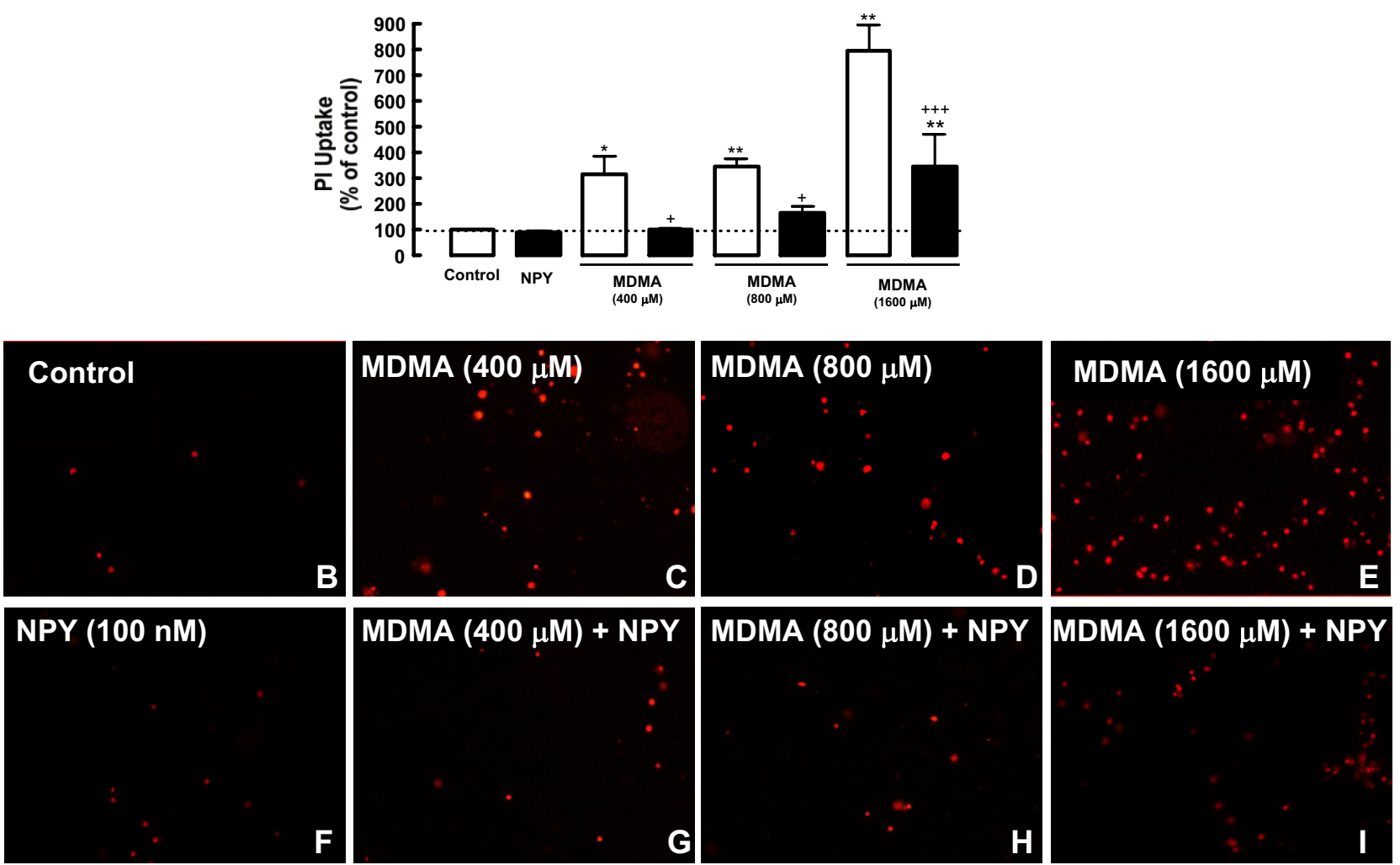

Fig. 4. NPY protects retinal cells against MDMA-induced cell death. NPY $(100 \mathrm{nM})$ was added to the cultures $1 \mathrm{~h}$ before the incubation with MDMA $\left(400,800,1600 \mu \mathrm{M}, 48 \mathrm{~h}, 37^{\circ} \mathrm{C}\right)$. The results are expressed as percentage of PI positive cells in control conditions (no drug), and represent the mean \pm S.E.M. of at least three independent experiments. ${ }^{*} P<0.05,{ }^{* *} P<0.01$ compared with control, Dunnet's post hoc test; ${ }^{+} P<0.05,{ }^{+++} P<0.001$ compared with MDMA, Bonferroni's post hoc test.

\section{DISCUSSION}

The injurious effects of MDMA in various brain regions, including cortex, striatum and thalamus, are widely recognized (Commins et al., 1987; Schmued, 2003). The neurotoxicity induced by MDMA was also demonstrated in cultured rat cortical neurons (Capela et al., 2006; Warren et al., 2006), liver cells (Montiel-Duarte et al., 2002), cerebella granule cells (Jimenez et al., 2004), and PC12 cells (Milhazes et al., 2006). Although some studies showed that considerable amounts of MDMA can reach the vitreous humor and the eye globe (Clauwaert et al., 2000; De Letter et al., 2000, 2002), the toxic effect of MDMA on the retina is not completely elucidated. MDMA causes retinal hemorrhage (Jacks and Hykin, 1998), impairment of retinal function (Firth, 2006) and central serous chorioretinopathy (Michael et al., 2003). In the present study, we showed that MDMA induced toxicity in cultured rat retinal neural cells in a concentration- and temperature-dependent manner. Our findings are correlated with the neurotoxic effect caused by MDMA in the retina, in vivo, reported recently (Miranda et al., 2007). It was shown that MDMA administration induces an increase in the production of oxygen- and nitrogenderived species, which in turn can cause retinal cell degeneration.
MDMA causes hyperthermia in humans and rats, and MDMA-induced hyperthermia can be fatal (Henry, 1992; Green et al., 2003). Previous studies also showed that hyperthermia plays a role in MDMA-induced neuronal death (Broening et al., 1995; Farfel and Seiden, 1995). In rat retinal cells, the toxic effect of MDMA was potentiated by increasing the incubation temperature to $40^{\circ} \mathrm{C}$. Similar results were obtained by others using cultured rat cortical neurons (Capela et al., 2006). Although neurodegeneration induced by MDMA has been reported to occur in normothermic animals (Broening et al., 1995; Farfel and Seiden, 1995), long-term neurotoxic effects of MDMA have been shown to be related to hyperthermia produced by the drug (Broening et al., 1995). The prevention of MDMAinduced hyperthermia decreases its neurotoxicity, and drugs that protect against MDMA-induced neurotoxicity also decrease body temperature (Farfel and Seiden, 1995; Malberg et al., 1996). The pathologic pathways involved in the aggravation of MDMA-induced toxicity by hyperthermia are not completely understood, though oxidative stress (Carvalho et al., 2001, 2002) activation of inflammatory processes (Roth et al., 2006) may have an important role in this interaction.

Recently, we showed that different cell types, such as neurons, astrocytes, Müller and microglial cells, are 

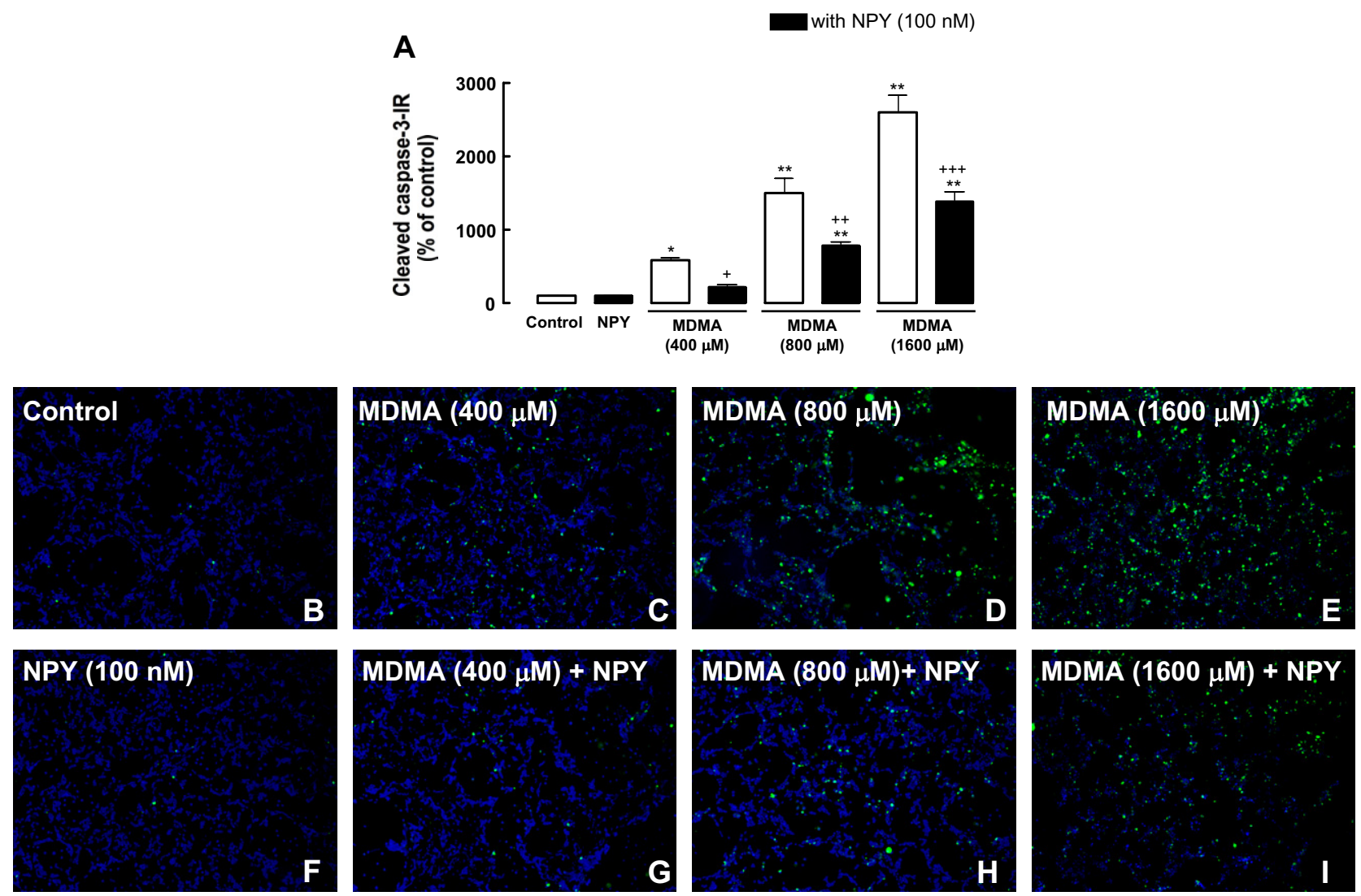

Fig. 5. NPY inhibits the increase in the activation of caspase- 3 induced by MDMA. NPY (100 nM) was added to cell cultures $1 \mathrm{~h}$ prior to MDMA incubations $\left(400,800,1600 \mu \mathrm{M}, 48 \mathrm{~h}, 37^{\circ} \mathrm{C}\right)$. The results are expressed as percentage of cleaved caspase-3 positive cells (green) in control conditions (no drug, B), and represent the mean \pm S.E.M. of at least three independent experiments. ${ }^{*} P<0.05$, ${ }^{*} P<0.01$ compared with control, Dunnet's post hoc test; ${ }^{+} P<0.05,{ }^{++} P<0.01,{ }^{+++} P<0.001$ compared with MDMA; Bonferroni's post hoc test.

present in rat retinal cell cultures (Álvaro et al., 2007). In the present work, we show that MDMA is toxic to neurons, astrocytes and Müller cells (GFAP-positive cells), and microglial cells. Furthermore, we found that retinal neurons and microglial cells were less resistant to MDMA exposure than GFAP-positive cells, since the toxic effect of MDMA on both cell types is more evident at the lower concentration used. The toxic effect of MDMA on glial cells has not been reported in previous studies. However, the methods utilized in in vitro studies to analyze the toxic effect of MDMA do not distinguish between cell death of astrocytes and neurons, but glial cells could have also been affected (Stumm et al., 1999; Capela et al., 2006; Cunha-Oliveira et al., 2006). Retinal glial cell death induced by MDMA might also suggest a higher susceptibility of retinal glial cells compared with brain glial cells. In vivo studies have evaluated the reactivity of brain glial cells, and not glial cell death. It was found that MDMA administration does not change GFAP expression (Wang et al., 2004) or increases GFAP expression and microglial activation (Orio et al., 2004; Baumann et al., 2007) in rat brain. In fact, the in vivo effect of MDMA on glial cells is still a matter of controversy, and further studies are necessary to clarify whether MDMA only induces glial cell reactivity in the brain, or if glial cell death can also occur, in addition to neuronal cell death.
After MDMA incubation we also observed a decrease in the number of neurons and reduction in the length of cytoplasmic processes compared with control conditions. It is well documented that MDMA produces long-term damage to nerve terminals in dopaminergic and serotonergic neurons (Quinton and Yamamoto, 2006). Several studies have also implicated the $5-\mathrm{HT}_{2 \mathrm{~A}}$-receptor in the mechanism of MDMA-induced brain toxicity (Schmidt et al., 1990; Johnson et al., 1993; Malberg et al., 1996; Capela et al., 2006, 2007). Given that these receptors are present in the retina (Pootanakit et al., 1999), we investigated the involvement of $5-\mathrm{HT}_{2 \mathrm{~A}}$-receptors in MDMA-induced cell toxicity in cultured retinal neural cells. The results indicate that MDMA-induced toxicity in retinal cells is partially dependent on the direct activation of $5-\mathrm{HT}_{2 \mathrm{~A}}$-receptor, since ketanserin significantly inhibited the cell death induced by MDMA. Similar results were found previously in cultured rat cortical neurons (Capela et al., 2006, 2007). In humans and rats, acute and chronic administration of MDMA decreases cortical 5- $\mathrm{HT}_{2 \mathrm{~A}}$-receptor density (Reneman et al., 2002). In vivo, ketanserin and other $5-\mathrm{HT}_{2 \mathrm{~A}}$-receptor antagonists showed efficacy in preventing neuronal damage in rats, but this effect was correlated to the hypothermic effect induced by the antagonists alone (Schmidt et al., 1990; Johnson et al., 1993; Malberg et al., 1996). 
In the present study, and for the first time, we describe the protective effect of NPY against MDMA toxicity. The neuroprotective role of NPY in the CNS is well documented. NPY protects hippocampal and cortical neurons exposed to excitotoxic conditions (Silva et al., 2003b, 2005a; Wu and Li, 2005; Domin et al., 2006; Xapelli et al., 2007) and has a protective role against methamphetamine (METH) -induced neuronal apoptosis in the mouse striatum (Thiriet et al., 2005). Our results show the involvement of $5-\mathrm{HT}_{2 \mathrm{~A}}$-receptors and a protective role of NPY on MDMA-induced retinal neural cell death. It was described that activation of $5-\mathrm{HT}_{2 \mathrm{~A}}$-receptors promoted neuronal firing by enhancing the sensitivity of glutamatergic AMPAreceptors and increasing intracellular calcium concentration $\left(\left[\mathrm{Ca}^{2+}\right]_{\mathrm{i}}\right)$ (Azmitia, 2001). Moreover, it has been suggested that glutamate might be involved in MDMA toxicity, since the NMDA antagonist, MK-801, protects against MDMA toxicity (Battaglia et al., 2002; Capela et al., 2006). The protective effect of NPY may be linked to its inhibitory effect on glutamate release, as found in rat hippocampus (Silva et al., 2003a, 2005b). Indeed, we show that NPY prevents glutamate-induced retinal neural cell death, measured by PI uptake. Moreover, we also found that NPY inhibits the increase in $\left[\mathrm{Ca}^{2+}\right]_{i}$ and glutamate release in these cultures (unpublished observations).

Therefore, the putative mechanism of MDMA-induced toxicity may involve an excessive release of glutamate caused by $5-\mathrm{HT}_{2 \mathrm{~A}}$-receptor activation, and consequently an increase in $\left[\mathrm{Ca}^{2+}\right]_{i}$ that could be prevented by the presence of NPY.

Besides necrotic death, several evidences suggest that apoptosis, which is often accompanied by caspase activation, may underlie drug abuse neurotoxicity. Our results show that retinal neural cells exposed to MDMA also die by a caspase-dependent apoptotic pathway, which are in agreement with in vivo and in vitro studies reporting that MDMA stimulates apoptotic cell death by activating caspase-3 in rat cortical neurons (Stumm et al., 1999; Meyer et al., 2004; Capela et al., 2006, 2007; CunhaOliveira et al., 2006), PC12 cells (Milhazes et al., 2006), rat primary cerebrocortical neurons (Warren et al., 2006), human serotonergic cells (Simantov and Tauber, 1997) and in rat limbic system (Tamburini et al., 2006). In order to dissect the mechanism of the neuroprotection induced by NPY, we investigated the protective effect of this peptide on apoptotic cell death caused by MDMA. Our results show that exogenous NPY decreases cleaved caspase-3 immunoreactivity in rat retinal cells in culture. Similar results were also found for kainate-induced toxicity in primary neocortical and hippocampal neurons in culture (Domin et al., 2006).

\section{CONCLUSION}

In conclusion, we showed that MDMA causes necrotic and apoptotic cell death in retinal neural cells in a concentration-dependent manner that is potentiated by elevated temperature. The toxic effect of MDMA is partially depen- dent on $5-\mathrm{HT}_{2 \mathrm{~A}}$-receptor activation and is significantly reduced by exogenous NPY.

Acknowledgments-This work was supported by the Fundação para a Ciência e a Tecnologia, Portugal (PTDC/SAU-NEU/73119/ 2006, SFRHIBD/10394/2002, SFRH/BD/12900/2003, SFHR/BPD/ 17196/2004) and FEDER, and by the Faculty of Medicine of the University of Coimbra (GAI 01/07). The authors would also like to acknowledge João Capela, Paulo Santos, and Armando Cristóvão for essential discussion of this work, and Ana Lúcia Tavares for technical support. We also would like to thank Dr. Alistair Barber for carefully reading the revised version of the manuscript.

\section{REFERENCES}

Álvaro AR, Rosmaninho-Salgado J, Santiago AR, Martins J, Aveleira C, Santos PF, Pereira T, Gouveia D, Carvalho AL, Grouzmann E, Ambrósio AF, Cavadas C (2007) NPY in rat retina is present in neurons, in endothelial cells and also in microglial and Müller cells. Neurochem Int 50:757-763.

Azmitia EC (2001) Modern views on an ancient chemical: serotonin effects on cell proliferation, maturation, and apoptosis. Brain Res Bull 56:413-424.

Battaglia G, Fornai F, Busceti CL, Aloisi G, Cerrito F, De Blasi A, Melchiorri D, Nicoletti F (2002) Selective blockade of mGlu5 metabotropic glutamate receptors is protective against methamphetamine neurotoxicity. J Neurosci 22:2135-2141.

Baumann MH, Wang X, Rothman RB (2007) 3,4-Methylenedioxymethamphetamine (MDMA) neurotoxicity in rats: a reappraisal of past and present findings. Psychopharmacology (Berl) 189:407-424.

Broening HW, Bowyer JF, Slikker W Jr (1995) Age-dependent sensitivity of rats to the long-term effects of the serotonergic neurotoxicant (+I-)-3,4-methylenedioxymethamphetamine (MDMA) correlates with the magnitude of the MDMA-induced thermal response. J Pharmacol Exp Ther 275:325-333.

Bruun A, Tornqvist K, Ehinger B (1986) Neuropeptide Y (NPY) immunoreactive neurons in the retina of different species. Histochemistry $86: 135-140$.

Cadet JL, Krasnova IN, Jayanthi S, Lyles J (2007) Neurotoxicity of substituted amphetamines: molecular and cellular mechanisms. Neurotox Res 11:183-202.

Capela JP, Fernandes E, Remiao F, Bastos ML, Meisel A, Carvalho F (2007) Ecstasy induces apoptosis via $5-\mathrm{HT}(2 \mathrm{~A})$-receptor stimulation in cortical neurons. Neurotoxicology 28:868-875.

Capela JP, Ruscher K, Lautenschlager M, Freyer D, Dirnagl U, Gaio AR, Bastos ML, Meisel A, Carvalho F (2006) Ecstasy-induced cell death in cortical neuronal cultures is serotonin 2A-receptor-dependent and potentiated under hyperthermia. Neuroscience 139:10691081.

Carvalho M, Carvalho F, Bastos ML (2001) Is hyperthermia the triggering factor for hepatotoxicity induced by 3,4-methylenedioxymethamphetamine (ecstasy)? An in vitro study using freshly isolated mouse hepatocytes. Arch Toxicol 74:789-793.

Carvalho M, Carvalho F, Remiao F, de Lourdes Pereira M, Pires-dasNeves R, de Lourdes Bastos M (2002) Effect of 3,4-methylenedioxymethamphetamine ("ecstasy") on body temperature and liver antioxidant status in mice: influence of ambient temperature. Arch Toxicol 76:166-172.

Clauwaert KM, Van Bocxlaer JF, De Letter EA, Van Calenbergh S, Lambert WE, De Leenheer AP (2000) Determination of the designer drugs 3,4-methylenedioxymethamphetamine, 3,4-methylenedioxyethylamphetamine, and 3,4-methylenedioxyamphetamine with HPLC and fluorescence detection in whole blood, serum, vitreous humor, and urine. Clin Chem 46:1968-1977.

Commins DL, Vosmer G, Virus RM, Woolverton WL, Schuster CR, Seiden LS (1987) Biochemical and histological evidence that methylenedioxymethylamphetamine (MDMA) is toxic to neurons in the rat brain. J Pharmacol Exp Ther 241:338-345. 
Cunha-Oliveira T, Rego AC, Cardoso SM, Borges F, Swerdlow RH, Macedo T, de Oliveira CR (2006) Mitochondrial dysfunction and caspase activation in rat cortical neurons treated with cocaine or amphetamine. Brain Res 1089:44-54.

D'Angelo I, Brecha NC (2004) Y2 receptor expression and inhibition of voltage-dependent $\mathrm{Ca}(2+)$ influx into rod bipolar cell terminals. Neuroscience 125:1039-1049.

De Letter EA, Belpaire FM, Clauwaert KM, Lambert WE, Van Bocxlaer JF, Piette MH (2002) Post-mortem redistribution of 3,4-methylenedioxymethamphetamine (MDMA, "ecstasy") in the rabbit. Part II: post-mortem infusion in trachea or stomach. Int $\mathrm{J}$ Legal Med 116:225-232.

De Letter EA, De Paepe P, Clauwaert KM, Belpaire FM, Lambert WE, Van Bocxlaer JF, Piette MHA (2000) Is vitreous humour useful for the interpretation of 3,4-methylenedioxymethamphetamine (MDMA) blood levels? Int J Legal Med 114:29-35.

Domin H, Kajta M, Smialowska M (2006) Neuroprotective effects of MTEP, a selective mGluR5 antagonists and neuropeptide $Y$ on the kainate-induced toxicity in primary neuronal cultures. Pharmacol Rep 58:846-858.

Farfel GM, Seiden LS (1995) Role of hypothermia in the mechanism of protection against serotonergic toxicity. II. Experiments with methamphetamine, p-chloroamphetamine, fenfluramine, dizocilpine and dextromethorphan. J Pharmacol Exp Ther 272:868-875.

Firth AY (2006) Editorial: ocular effects of criminal drug use. Can J Ophthalmol 41:140-146.

Green AR, Mechan AO, Elliott JM, O'Shea E, Colado MI (2003) The pharmacology and clinical pharmacology of 3,4-methylenedioxymethamphetamine (MDMA, "ecstasy"). Pharmacol Rev 55:463-508.

Henry JA (1992) Ecstasy and the dance of death. BMJ 305:5-6.

Hutsler JJ, Chalupa LM (1995) Development of neuropeptide Y immunoreactive amacrine and ganglion cells in the pre- and postnatal cat retina. J Comp Neurol 361:152-164.

Jacks AS, Hykin PG (1998) Retinal haemorrhage caused by "ecstasy." Br J Ophthalmol 82:842-843.

Jen PY, Li WW, Yew DT (1994) Immunohistochemical localization of neuropeptide $Y$ and somatostatin in human fetal retina. Neuroscience 60:727-735.

Jimenez A, Jorda EG, Verdaguer E, Pubill D, Sureda FX, Canudas AM, Escubedo E, Camarasa J, Camins A, Pallas M (2004) Neurotoxicity of amphetamine derivatives is mediated by caspase pathway activation in rat cerebellar granule cells. Toxicol Appl Pharmacol 196:223-234.

Johnson M, Bush LG, Hanson GR, Gibb JW (1993) Effects of ritanserin on the 3,4-methylenedioxymethamphetamine-induced decrease in striatal serotonin concentration and on the increase in striatal neurotensin and dynorphin A concentrations. Biochem Pharmacol 46:770-772.

Malberg JE, Sabol KE, Seiden LS (1996) Co-administration of MDMA with drugs that protect against MDMA neurotoxicity produces different effects on body temperature in the rat. J Pharmacol Exp Ther 278:258-267.

Malberg JE, Seiden LS (1998) Small changes in ambient temperature cause large changes in 3,4-methylenedioxymethamphetamine (MDMA)-induced serotonin neurotoxicity and core body temperature in the rat. J Neurosci 18:5086-5094.

Meyer JS, Grande M, Johnson K, Ali SF (2004) Neurotoxic effects of MDMA ("ecstasy") administration to neonatal rats. Int J Dev Neurosci 22:261-271.

Michael JC, Pak J, Pulido J, de Venecia G (2003) Central serous chorioretinopathy associated with administration of sympathomimetic agents. Am J Ophthalmol 136:182-185.

Michel MC, Beck-Sickinger A, Cox H, Doods HN, Herzog H, Larhammar D, Quirion R, Schwartz T, Westfall T (1998) XVI International Union of Pharmacology recommendations for the nomenclature of neuropeptide $Y$, peptide $Y Y$, and pancreatic polypeptide receptors. Pharmacol Rev 50:143-150.
Milhazes N, Cunha-Oliveira T, Martins P, Garrido J, Oliveira C, Rego AC, Borges F (2006) Synthesis and cytotoxic profile of 3,4-methylenedioxymethamphetamine ("ecstasy") and its metabolites on undifferentiated PC12 cells: a putative structure-toxicity relationship. Chem Res Toxicol 19:1294-1304.

Miranda M, Bosch-Morell F, Johnsen-Soriano S, Barcia J, Almansa I, Asensio S, Araiz J, Messeguer A, Romero FJ (2007) Oxidative stress in rat retina and hippocampus after chronic MDMA ("ecstasy") administration. Neurochem Res 32:1156-1162.

Montiel-Duarte C, Varela-Rey M, Oses-Prieto JA, Lopez-Zabalza MJ, Beitia G, Cenarruzabeitia E, Iraburu MJ (2002) 3,4-Methylenedioxymethamphetamine ("ecstasy") induces apoptosis of cultured rat liver cells. Biochim Biophys Acta 1588:26-32.

Mosmann T (1983) Rapid colorimetric assay for cellular growth and survival: application to proliferation and cytotoxicity assays. J Immunol Methods 65:55-63.

Oh SJ, D'Angelo I, Lee EJ, Chun MH, Brecha NC (2002) Distribution and synaptic connectivity of neuropeptide $\mathrm{Y}$-immunoreactive amacrine cells in the rat retina. J Comp Neurol 446:219-234.

Orio L, O'Shea E, Sanchez V, Pradillo JM, Escobedo I, Camarero J, Moro MA, Green AR, Colado MI (2004) 3,4-Methylenedioxymethamphetamine increases interleukin-1 beta levels and activates microglia in rat brain: studies on the relationship with acute hyperthermia and 5-HT depletion. J Neurochem 89:1445-1453.

Parrott AC (2005) Chronic tolerance to recreational MDMA (3,4-methylenedioxymethamphetamine) or ecstasy. J Psychopharmacol 19:71-83.

Pootanakit K, Prior KJ, Hunter DD, Brunken WJ (1999) 5-HT2a receptors in the rabbit retina: potential presynaptic modulators. Vis Neurosci 16:221-230.

Quinton MS, Yamamoto BK (2006) Causes and consequences of methamphetamine and MDMA toxicity. AAPS J 8:E337-E347.

Reneman L, Endert E, de Bruin K, Lavalaye J, Feenstra MG, de Wolff FA, Booij J (2002) The acute and chronic effects of MDMA ("ecstasy") on cortical 5-HT2A receptors in rat and human brain. Neuropsychopharmacology 26:387-396.

Ricaurte GA, DeLanney LE, Wiener SG, Irwin I, Langston JW (1988a) 5 -Hydroxyindoleacetic acid in cerebrospinal fluid reflects serotonergic damage induced by 3,4-methylenedioxymethamphetamine in CNS of non-human primates. Brain Res 474:359-363.

Ricaurte GA, Forno LS, Wilson MA, DeLanney LE, Irwin I, Molliver ME, Langston JW (1988b) (+/-)3,4-Methylenedioxymethamphetamine selectively damages central serotonergic neurons in nonhuman primates. JAMA 260:51-55.

Ricaurte GA, Martello AL, Katz JL, Martello MB (1992) Lasting effects of (+-)-3,4-methylenedioxymethamphetamine (MDMA) on central serotonergic neurons in nonhuman primates: neurochemical observations. J Pharmacol Exp Ther 261:616-622.

Ricaurte GA, Yuan J, McCann UD (2000) (+/-)3,4-Methylenedioxymethamphetamine ("ecstasy")-induced serotonin neurotoxicity: studies in animals. Neuropsychobiology 42:5-10.

Roth J, Rummel C, Barth SW, Gerstberger R, Hubschle T (2006) Molecular aspects of fever and hyperthermia. Neurol Clin 24:421439, v.

Santiago AR, Pereira TS, Garrido MJ, Cristovao AJ, Santos PF, Ambrosio AF (2006) High glucose and diabetes increase the release of $[3 \mathrm{H}]-d-a s p a r t a t e$ in retinal cell cultures and in rat retinas. Neurochem Int 48:453-458.

Schmidt CJ (1987) Neurotoxicity of the psychedelic amphetamine, methylenedioxymethamphetamine. J Pharmacol Exp Ther 240:1-7.

Schmidt CJ, Black CK, Taylor VL (1990) Antagonism of the neurotoxicity due to a single administration of methylenedioxymethamphetamine. Eur J Pharmacol 181:59-70.

Schmued LC (2003) Demonstration and localization of neuronal degeneration in the rat forebrain following a single exposure to MDMA. Brain Res 974:127-133. 
Silva AP, Carvalho AP, Carvalho CM, Malva JO (2003a) Functional interaction between neuropeptide $Y$ receptors and modulation of calcium channels in the rat hippocampus. Neuropharmacology 44:282-292.

Silva AP, Pinheiro PS, Carvalho AP, Carvalho CM, Jakobsen B, Zimmer J, Malva JO (2003b) Activation of neuropeptide Y receptors is neuroprotective against excitotoxicity in organotypic hippocampal slice cultures. FASEB J 17:1118-1120.

Silva AP, Cavadas C, Grouzmann E (2002) Neuropeptide $Y$ and its receptors as potential therapeutic drug targets. Clin Chim Acta 326:3-25.

Silva AP, Xapelli S, Grouzmann E, Cavadas C (2005a) The putative neuroprotective role of neuropeptide $Y$ in the central nervous system. Curr Drug Targets CNS Neurol Disord 4:331-347.

Silva AP, Xapelli S, Pinheiro PS, Ferreira R, Lourenco J, Cristovao A, Grouzmann E, Cavadas C, Oliveira CR, Malva JO (2005b) Upregulation of neuropeptide $Y$ levels and modulation of glutamate release through neuropeptide $Y$ receptors in the hippocampus of kainate-induced epileptic rats. J Neurochem 93:163-170.

Simantov R, Tauber M (1997) The abused drug MDMA (ecstasy) induces programmed death of human serotonergic cells. FASEB $\mathrm{J}$ 11:141-146.

Stone DM, Stahl DC, Hanson GR, Gibb JW (1986) The effects of 3,4-methylenedioxymethamphetamine (MDMA) and 3,4-methylenedioxyamphetamine (MDA) on monoaminergic systems in the rat brain. Eur J Pharmacol 128:41-48.

Stumm G, Schlegel J, Schafer T, Wurz C, Mennel HD, Krieg JC, Vedder H (1999) Amphetamines induce apoptosis and regulation of bcl-x splice variants in neocortical neurons. FASEB $\mathrm{J}$ 13:1065-1072.

Tamburini I, Blandini F, Gesi M, Frenzilli G, Nigro M, Giusiani M, Paparelli A, Fornai $F$ (2006) MDMA induces caspase-3 activation in the limbic system but not in striatum. Ann $N$ Y Acad Sci 1074:377-381.

Thiriet N, Deng X, Solinas M, Ladenheim B, Curtis W, Goldberg SR, Palmiter RD, Cadet JL (2005) Neuropeptide $Y$ protects against methamphetamine-induced neuronal apoptosis in the mouse striatum. J Neurosci 25:5273-5279.

Wang X, Baumann MH, Xu H, Rothman RB (2004) 3,4-Methylenedioxymethamphetamine (MDMA) administration to rats decreases brain tissue serotonin but not serotonin transporter protein and glial fibrillary acidic protein. Synapse 53:240-248.

Warren MW, Zheng W, Kobeissy FH, Cheng Liu M, Hayes RL, Gold MS, Larner SF, Wang KK (2006) Calpain- and caspase-mediated alphall-spectrin and tau proteolysis in rat cerebrocortical neuronal cultures after ecstasy or methamphetamine exposure. Int $\mathrm{J}$ Neuropsychopharmacol 1-11.

Warren MW, Larner SF, Kobeissy FH, Brezing CA, Jeung JA, Hayes RL, Gold MS, Wang KK (2007) Calpain and caspase proteolytic markers co-localize with rat cortical neurons after exposure to methamphetamine and MDMA. Acta Neuropathol (Berl) 114: 277-286.

Wettstein JG, Earley B, Junien JL (1995) Central nervous system pharmacology of neuropeptide Y. Pharmacol Ther 65:397-414.

Wu YF, Li SB (2005) Neuropeptide Y expression in mouse hippocampus and its role in neuronal excitotoxicity. Acta Pharmacol Sin 26:63-68.

Xapelli S, Silva AP, Ferreira R, Malva JO (2007) Neuropeptide Y can rescue neurons from cell death following the application of an excitotoxic insult with kainate in rat organotypic hippocampal slice cultures. Peptides 28:288-294.

Xie T, Tong L, McLane MW, Hatzidimitriou G, Yuan J, McCann U, Ricaurte G (2006) Loss of serotonin transporter protein after MDMA and other ring-substituted amphetamines. Neuropsychopharmacology 31:2639-2651. 